\title{
The Evaluation of Client Service Provided by the Human Resource Division of a National Service Organisation
}

\author{
H E Brand and N Joubert
}

Department of Human Resource Management, University of Pretoria

JEL M 12

\section{ABSTRACT}

The aim of this study is to evaluate the quality of internal client service of the human resource division of a national service organisation. Two studies were in fact conducted, one involving 388 clients of the relevant division, and the other 99 human resource practitioners in the same division. Separate questionnaires were completed in the two samples. Results show that communication with clients, service provision and quality and competency of the human resource personnel are important problems to be addressed by management. The implementation of an achievement acknowledgement system, the re-evaluation of the divisional structure and functioning, and upgrading service provision skills could also assist the division in improving its client service competency.

South African business organisations today increasingly experience the pressure of national and international competition, as well as the extremely important role of effective and outstanding client service in this process. These realities force organisations again to realise the basic fact that the difference between success and failure largely depends on the quality of client service provided by employees and management (Band, 1991). Client service excellence forms an integral part of the rapidly changing and quality conscious competing markets (Cottle, 1990). It is also realised that quality service depends not only on modern technology, but especially on the attitudes and abilities of people. Perceptions of service are the result of certain expectations and experiences of the service provided (Friedmann, 1998). Clients' expectations influence their evaluation of service quality, which implies that the services rendered should adequately meet client requisites (Brennan, 1997).

Employees and the various sectors of an organisation are also increasingly becoming dependent on internal service providers for delivering their own services efficiently and reaching their objectives. Research by Schneider of the University 
of Maryland in the early 1980s already showed an important relation between the extemal and intemal client satisfaction of different departments in various organisations, indicating that the quality of internal client service can clearly promote or damage the external client service of an organisation (Hoffman, 1997). According to Chang, Kelly and Irvine (1994), it appears that the internal and extemal clients of organisations have comparable experiences with service providers. Internal clients, however, do not often have much of a choice in utilising altemative services and products, and are largely dependent on the services of internal service providers. This situation is, however changing rapidly, as organisations are increasingly beginning to outsource the traditional services of internal service providers, such as information technology, marketing, communication management and human resources. Thus the pressure is on all service and support sectors in the corporate environment to effectively assess the value and quality of their services to their internal clients, utilising the results of such investigations to promote outstanding client service, comparable to the services rendered to extemal clients of the company. The quality of intemal client service today often determine the difference between keeping or outsourcing internal service functions in business organisations.

Within the framework of the above-mentioned corporate realities, the human resource division of the specific national service organisation discussed here, also had to urgently evaluate its quality of internal client service, which lead to the planning and execution of this study. The primary objective of the study was to evaluate the intemal client service provided by this division. Other objectives were to evaluate the satisfaction of the division's personnel with their service provision, as well as to determine the obstacles in the way of effective service provision. The philosophy of this division regarding its own objective in the organisation may be best described by the following statement by Band (1991: 272) : "....viewing employees as intemal customers, viewing jobs as intemal products, and then endeavouring to offer intemal products and services to satisfy the needs and wants of these internal customers while addressing the objectives of the organisation ".

In the present study, the following three pairs of hypotheses were formulated and tested:

$\mathrm{H}_{0}$ : The client service rendered by the human resource division of the organisation is perceived as unsatisfactory by its intemal clients.

$H_{1}$ : The client service rendered by the human resource division of the organisation is perceived as satisfactory by its intemal clients.

$\mathrm{H}_{0}$ : The practitioners employed in the human resource division of the organisation do not perceive their client service as satisfactory.

$\mathrm{H}_{2}$ : The practitioners employed in the human resource division of the organisation perceive their client service as satisfactory. 
$H_{4}$ : The practitioners employed in the human resource division of the organisation did not identify any obstacles to effective client service provided by the division.

$\mathrm{H}_{3}$ : The practitioners employed in the human resource division of the organisation did identify obstacles to effective client service provided by the division.

\section{RESEARCH METHOD}

The research method followed in this study are discussed under the headings of research strategy, research group, sample, response rate and data analysis.

\section{RESEARCH STRATEGY}

The survey method in this study to determine the factors influencing the provision of internal client service of the human resource division, was to use two questionnaires as measuring instruments. One of these questionnaires was applied to internal clients of the division in the organisation (referred to as the client study), while the other questionnaire, consisting of two sections, was applied to human resource practitioners employed in the human resource division (referred to as the practitioner study). The questionnaires were distributed together with an information brochure indicating the motivation and characteristics of the study, as well as the relevant instructions. It was also clearly indicated that the study was conducted with the approval and support of the top management of the organisation.

The following are the particulars of the two questionnaires :

\section{The client study:}

A 32-item questionnaire was used in this part of the study. The critical dimensions of the client service model of Piorier \& Houser (1993) was used in the construction of the instrument. The questionnaire was tested for reliability, obtaining a Cronbach's Alpha of 0,70 .

The seven dimensions evaluated by the model are the following :

- $\quad$ Accessibility (of division personnel)

- Technical skills/competencies (of the personnel)

- Attitude and climate (of personnel and the division respectively)

- Communication

- Credibility (of the personnel) 
Quality of services and structure efficiency (of personnel and the division)

- Speed of service provision

The practitioner study:

A 75-item questionnaire, consisting of two sections, $A$ and $B$, was constructed by utilising two questionnaires, namely :

Section A : The "Self - test on the Service Capabilities Package" of Whiteley (1991), for the evaluation of the satisfaction level of the human resource division personnel. The seven evaluation dimensions contained in this questionnaire are the following :

- Vision, commitment and climate (of the division)

- $\quad$ Focus on client needs

- Readiness to anticipate and solve client problems

- Use and communication of client information

- Reaching out to clients

- Capability and capacity

- Continuous improvement of products and services

Section B: The "Team Review Survey" of Francis \& Young (1992) was used for the evaluation of obstacles of effective service provision to internal clients of the division. The twelve evaluation dimensions here are :

- Insufficient leadership

- Unqualified leadership

- Insufficient group involvement

- Non - constructive climate

- Low goal achievement orientation

- Under-developed corporative role

- Ineffective work methods

- Insufficient role clarity

- Ineffective handling of criticism

- Insufficient individual development

- $\quad$ Lack of creative capacity

- Negative inter - group relations

As regards reliability, the questionnaire of Whiteley (1991), indicated a Cronbach's coefficient Alpha of 0,71, while the questionnaire of Francis \& Young (1992) had a reported Alpha coefficient of 0,85 . 


\section{RESEARCH GROUP}

The research group was divided into two parts. One consisted out of all the internal clients of the human resource division in the particular service organisation, numbering a total of 2277 subjects. The other comprised all human resource practitioners employed in the human resource division, a total of 99 subjects.

\section{SAMPLE}

For the client study, 719 internal clients were selected on a stratified, randomised basis from the total target population of 2277 subjects. The stratification was done according to place of work/geographical area and job grading (according to the Paterson grading system).

For the practitioner study, a convenience sample was utilised, including all practitioners employed in the human resource division.

\section{RESPONSE RATE}

A response rate of $54 \%(\mathrm{~N}=388)$ was obtained for the internal client sample, while a rate of $66 \%(\mathrm{~N}=66)$ was obtained for the practitioner sample.

\section{DATA ANALYSIS}

The data derived from these questionnaires were analysed by means of the descriptive statistics of the SPSS-Windows computer programme. The arithmetic mean of the various dimensions was used together with the various industrial norms of the questionnaires to determine the problematic dimensions in the process of internal client service by the human resource division of the organisation.

\section{RESULTS OF THE STUDY}

The client study:

As mentioned above, this section of the study focused on all internal clients of the human resource division, for example, corporative sections such as finance, marketing, engineering, commerce and information. 
The results obtained from the client study are shown in Table 1.

Table 1: Results of the internal client study

\begin{tabular}{|l|l|ll|}
\hline \multicolumn{1}{|c|}{ Dimension } & Mean & Norm(N) \& Ideal(I) \\
\hline Accessibility & 60,71 & N:68\% & I:77 \\
\hline Competency & 63,91 & N:72\% & I:77 \\
\hline Attitude and climate & 70,90 & N:68\% & I:77 \\
\hline Communication & 57,69 & N:59\% & I:77 \\
\hline Credibility & 62,92 & N:67\% & I:77 \\
\hline Services and structure & 61,35 & N:68\% & I:77 \\
\hline Service provision speed & 59,49 & N:59\% & I:77 \\
\hline \hline
\end{tabular}

According to Table 1 , the following six dimensions, in order of priority, seemingly do not measure up to the expectations of intemal clients of the human resource division:

- Communication with clients

- Availability of personnel of the human resource division

- $\quad$ Structure effectivity and service function of the division

- Credibility of personnel

- Competency of personnel

- Attitude of personnel and general service provision climate

Only the dimension attitude and climate proved to be somewhat above the industrial norm, but still far below the ideal norm. Thus the null hypothesis relating to this part of the study is supported and the alternative hypothesis rejected.

The practitioner study :

As indicated above, this section of the study consists out of two sections, namely: Section A: Evaluation of the perceptions by personnel of the human resource division concerning their service provision to internal clients.

Section B: The identification of obstacles to effective service provision by personnel of the division. 
The results obtained for section $\mathrm{A}$ are shown in Table 2.

Table 2: Section A : Evaluation of client service of division personnel by the personnel themselves

\begin{tabular}{|l|c|c|c|}
\hline \multicolumn{1}{|c|}{ Dimension } & Mean & $\begin{array}{c}\text { Industrial } \\
\text { norm }\end{array}$ & Ideal \\
\hline $\begin{array}{l}\text { Vision, connectedness } \\
\text { and climate }\end{array}$ & 64,50 & $62-68$ & $75+$ \\
\hline Focus on client needs & 57,27 & $62-68$ & $75+$ \\
\hline $\begin{array}{l}\text { Readiness to anticipate } \\
\text { and solve client } \\
\text { problems }\end{array}$ & 43,18 & $62-68$ & $75+$ \\
\hline $\begin{array}{l}\text { Use and } \\
\text { communication of } \\
\text { client information }\end{array}$ & 46,54 & $62-68$ & $75+$ \\
\hline \begin{tabular}{l} 
Reaching out to clients \\
\hline $\begin{array}{l}\text { Capability and } \\
\text { capacity }\end{array}$
\end{tabular} & 72,35 & $62-68$ & $75+$ \\
\hline $\begin{array}{l}\text { Continuous } \\
\text { improvement of } \\
\text { products and services }\end{array}$ & 35,71 & $62-68$ & $75+$ \\
\hline
\end{tabular}

Table 2 indicates that the personnel of the human resource division evaluate the following important client service dimensions, in order of importance, as unsatisfactory:

- The capability and capacity to provide for the needs of internal clients

- The continuous improvement of products and services

- Readiness to anticipate and solve client problems

The division's perception of its client service indicated only two of seven dimensions of service quality to be above the industrial norm, namely reaching out to clients and the vision, commitment and climate of the division. No dimension indicated a performance higher than or even near to the ideal $(75 \%)$ of an outstanding service division. 
Thus the null hypothesis relating to this part of the study is supported and the alternative hypothesis rejected.

The results obtained for section B are shown in Table 3.

Table 3 : Section B : Evaluation of obstacles to effective service provision by the human resource division

\begin{tabular}{|l|c|c|c|}
\hline \multicolumn{1}{|c|}{ Dimension } & Mean & $\begin{array}{c}\text { Industrial } \\
\text { norm }\end{array}$ & Ideal \\
\hline Insufficient leadership & 25,76 & $45-49$ & $20-$ \\
\hline Unqualified leadership & 23,11 & $45-49$ & $20-$ \\
\hline $\begin{array}{l}\text { Insufficient group } \\
\text { involvement }\end{array}$ & 19,32 & $45-49$ & $20-$ \\
\hline $\begin{array}{l}\text { Non-constructive } \\
\text { climate }\end{array}$ & 42,05 & $45-49$ & $20-$ \\
\hline $\begin{array}{l}\text { Low goal achievement } \\
\text { orientation }\end{array}$ & 20,46 & $45-49$ & $20-$ \\
\hline $\begin{array}{l}\text { Under-developed } \\
\text { corporative role }\end{array}$ & 21,59 & $45-49$ & $20-$ \\
\hline $\begin{array}{l}\text { Ineffective work } \\
\text { methods }\end{array}$ & 29,54 & $45-49$ & $20-$ \\
\hline \begin{tabular}{l} 
Insufficient role clarity \\
\hline $\begin{array}{l}\text { Ineffective handling of } \\
\text { criticism }\end{array}$
\end{tabular} & 28,03 & $45-49$ & $20-$ \\
\hline $\begin{array}{l}\text { Insufficient individual } \\
\text { development }\end{array}$ & 25,00 & $45-49$ & $20-$ \\
\hline $\begin{array}{l}\text { Lack of creative } \\
\text { capacity }\end{array}$ & 18,56 & $45-49$ & $20-$ \\
\hline $\begin{array}{l}\text { Negative inter-group } \\
\text { relations }\end{array}$ & 21,21 & $45-49$ & $20-$ \\
\hline
\end{tabular}

Table 3 indicates that the personnel employed in the human resource division apparently identified, in order of importance, the following serious obstacles to effective client service provision by the division: 
- A non-constructive climate in the division

- Ineffective handling of criticism

- Ineffective work methods

Thus the null hypothesis relating to this part of the study is supported and the alternative hypothesis rejected.

When comparing the important negative results of section $\mathrm{A}$ (selftest) and section B (obstacles), the following tendencies, set out in Table 4, are evident :

Table 4: Comparison of dimensions in section $A$ (selftest) and section $B$ (obstacles)

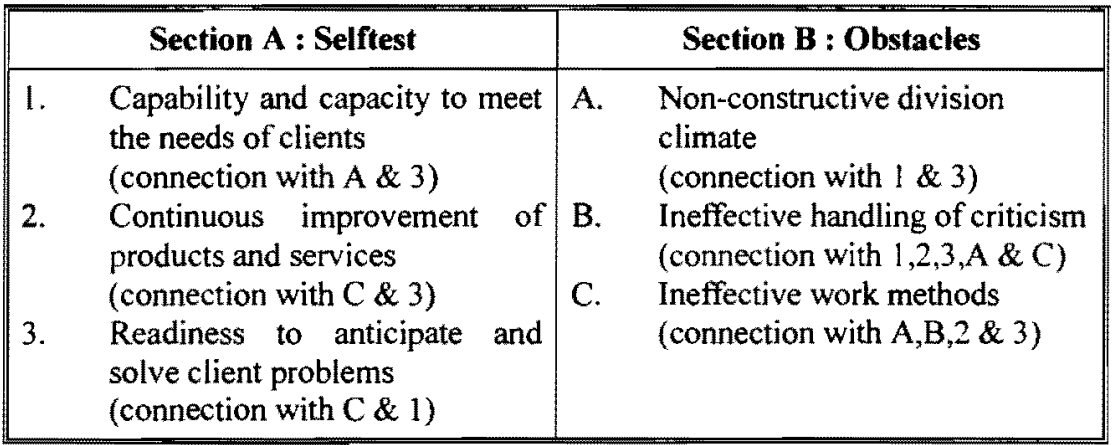

According to Table 4, the various negatively evaluated dimensions in Sections A and $B$ indicate an inter-dependent pattern. This tendency should be seriously taken into consideration when planning interventions or steps to improve these aspects of client service provision.

\section{CONCLUSIONS AND RECOMMENDATIONS}

The results of the study indicate that intemal clients' evaluation of the client service provided by the human resource division of the relevant national service organisation, identified some important problems that should be addressed. These were communication with clients, availability, credibility, competency and attitude of personnel in the human resource division, the structure effectivity and service function of the division, as well as the general service provision climate. These findings support those of Friedmann (1998) that client service is strongly influenced by the attitudes and abilities of service providers, and that perceptions of service relate to expectations and experiences of service provision. This also 
relates to the findings of Brennan (1997) that client expectations influence their experience of client service.

Personnel of the human resource division also identified some internal aspects that should receive attention in order to improve client service. The following perceptions emerged as being unsatisfactory : capability and capacity to provide effective service, lack of improvement of goods and services, and inability to anticipate and solve client problems. The human resource practitioners further identified a non-constructive climate in the division, ineffective handling of criticism and poor work methods as major hindrances.

The problematic dimensions identified in the various sections of the study (internal clients, division self-test and division obstacles) also show a high degree of concurrence. This tendency will probably make it easier to focus on the improvement of the dimensions which require urgent attention.

The following recommendations for improving the client service of the human resource division are suggested :

- A thorough management presentation of the results of the study to the personnel of the division.

- All personnel should participate in the process of discussion and deliberation of the results, as well as in any decision-making relating to client service improvement strategies.

- Results of the study should be presented to all internal clients of the division, accompanied with information on all actions and interventions to improve service provision.

- The primary focus should be on the solution of service provision problems in the division itself, as indicated by the results of the practitioner study.

- An effective communication strategy for internal clients is very important in order to promote the division and its goods and services.

- An evaluation of the structure and functioning of the division. Special emphasis should be placed on the availability of efficient personnel to effectively cater for the diverse needs and expectations of internal clients.

- The implementation of an achievement acknowledgement system for personnel of the division should be considered, through which internal clients, for example, can also recommend division personnel for acknowledgement of noteworthy achievements.

The technical and other skills and capabilities of personnel with regard to the provision of client service excellence should be evaluated and promoted.

- The credibility of the division and its functions should be confirmed and expanded. For this purpose the professional and ethical standards of the division should be determined and put into effect. 


\section{REFERENCES}

1. BAND, A.W. (1991) Creating Value for Customers: Designing and Implementing a Total Corporate Strategy, New York: J. Whitley \& Sons.

2. BRENNAN, C.D. (1997) Proactive Customer Service: Transforming Your Customer Service Department into a Profit Centre, New York: Amacom.

3. CHANG, R.Y., KELLY, P.K. \& IRVINE, C.A. (1994) Satisfying Internal Customers First, Irvine \& Chang Associates.

4. COTTLE, D.W. (1990) Client Centred Service: How to keep Them Coming Back for More, New York: Wiley.

5. FRANCIS, D. \& YOUNG, D. (1992) Improving Work Groups: A Practical Mamual for Team Building, Amsterdam: Pheiffer \& Company.

6. FRIEDMANN, N. (1998) Customer Service Nightmares: 100 Tales of the Worst Experiences, Los Altos, Califomia: Crisp Publications.

7. HOFFMAN, K.D. (1997) Essentials of Service Marketing, New York: Harcourt Brace College Publishers.

8. PIORIER, J. \& HOUSER, D. (1993) Business Partnering for Continuous Improvement, San Diego: Pheiffer \& Company.

9. WHITELY, R.C. (1991) The Customer Driven Company, Boston: Addison Company. 